\title{
Endophytes: An Environmental Friendly Bacteria for Plant Growth Promotion
}

\author{
Priyanka Batra $^{1^{*}}$, Monika Barkodia ${ }^{1}$, Umang Ahlawat ${ }^{1}$, Rekha Sansanwal ${ }^{1}$, \\ Tanisha Sharma ${ }^{2}$ and Leela Wati ${ }^{1}$ \\ ${ }^{1}$ CCS Haryana Agricultural University, Hisar, Haryana, India \\ ${ }^{2}$ National Research Centre on Equines, Hisar, Haryana, India
}

*Corresponding author

\section{A B S T R A C T}

Keywords

Biofertilizers,

Endophytes,

Ecofriendly,

Fertilizers, Rhizobial,

Nonrhizobial

Article Info

Accepted:

17 January 2018

Available Online:

10 February 2018
Environment pollution and the food shortage are the biggest problem faced by human beings. As the world population increase food requirement also increases. To fulfil the requirement of food the farmers are dependent on the chemical fertilizers which are harmful for environment. Thus the alternate to these problems are the use of biofertilizers. Both rhizobial and nonrhizobial endophytes are used as the biofertilizers as they have potential to increase the crop yield by producing plant growth promoting activity like Indole acetic acid (IAA), enzyme 1- aminocyclopropane-1-carboxylate (ACC) deaminase, potassium solubilization, phosphate solubilisation, siderophore production and most importantly the nitrogen fixation. As these endophytes have potential to meet the food requirements and as well as do not pollute the environment thus can be called as ecofriendly bacteria.

\section{Introduction}

Traditionally, plants have been considered as single organisms but in nature, plants associate with diverse organisms. The network of interactions between different symbiotic microorganisms and the host plant likely is likely to have a huge importance for the plant growth and development. Plant growth involves the synergistic activity of many different life forms in a highly complex environment. Thus the field of growing plant is a complex of microbial activity, comprising soil microbes, atmospheric microbes, plant surface microbes, an internal plant-colonizing microbes or endophytes. As the plant constitute vast and diverse niches for endophytic organisms, these endophytes living inside plants might intimately interact with cells of the host and release plant-growthpromoting compounds. This synergistic interaction between plant and endophytes has been called as double-fitness trait which is active in the plant endophyte partnership. This interaction is beneficial for both plant and endophytes, as the plants provide protection and photo assimilates on which endophytes are heavily dependent and in return endophytes promote growth of plants by their different mechanisms. Plant-endophyte 
interactions that promote plant development and plant health have been the subject of considerable interest. Among the endophytic microorganisms, endophytic bacteria occupy internal tissue of plants without causing damage to their hosts. Endophytic bacteria includes both rhizobial and nonrhizobial endophytes.

\section{Why endophytes are called as ecofriendly?}

As the world population increases, it is insufficient to fulfill the food demand of populations. So to feed the burgeoning population of the world, farmer heavily rely on the use of chemical fertilizers. These chemical fertilizers increase yield in agriculture but are expensive and harm the environment. They deplete nonrenewable energy resources, i.e. manufacturing of industrial nitrogen fertilizers uses nonrenewable resources like coal and natural gas and causes production of greenhouse gases contributing to global warming (Bhattacharjee et al., 2008). These fertilizers also have side effects, such as leaching out and polluting water basins, destroying micro-organisms and friendly insects, making the crop more susceptible to attack of diseases, reducing soil fertility, thereby causing irreparable damage to overall system. Therefore, it's high time to opt for alternative fertilizers which can be used in sustainable agricultural practices without affecting the environment. Application of plant growth promoting endophytic bacteria (PGPBEs) can be a potential option for enhancing growth and yield of leguminous plant in sustainable manner. The potential of PGPBEs to improve plant health has led to a great number of studies examining their applied use as inoculants, primarily in agricultural crops (Kloepper and Schroth, 1978; Hallmann et al., 1997; KuklinskySobral et al., 2004). As they are safe to environment so they are called ecofriendly (Fig. 1).

\section{History of endophytic microorganisms}

Heinrich Friedrich link (1809) was the German botanist who first describes the endophytes. At that time he gave term "Endophytae" and described as a distinct group of parasitic fungi living in plants. But De Bary (1866) was first to coined the term endophyte and Vogl (1898) was first who reported the mycelium lives in the grass seed Lolium temulentum. In 1904, in Germany Freeman identified an endophytic fungus, in Persian darnel (annual grass). Perotti (1926) was the first to describe the occurrence of nonpathogenic flora in root tissues and Henning and Villforth (1940) reported the presence of bacteria in the leaves, stems and roots of apparently healthy plants. Since 1940's there have been several reports on endophytic bacteria in various plant tissues (Hallmann et al., 1997). In the 1980's endophytic bacteria having nitrogen fixing ability were found in graminaceous plants (Reinhold-Hurek and Hurek, 1998). Evidence of plant associated microbes has been discovered in the fossilized tissues of stems and leaves (Taylor and Taylor, 2000).

\section{Definition of endophytes}

Researchers defined endophytes in various ways and these definitions have been modified as the research field advanced. Tervet and Hollis (1948) defined endophytes as microorganisms which have ability to live inside the plants without showing any disease symptoms. Petrini (1991) defined endophytes as "all organisms inhabiting plant organs that at some time in their life cycle can colonize internal plant tissues without causing apparent harm to their host". Kado (1992) defined 'Endophytic reside within the living organism without doing causing harm or gaining benefit other than securing residency. Microorganisms living within plant tissues for all or part of their life cycle without causing 
any visible symptoms of their presence are defined as endophytes (Wilson, 1993). Bacon and White (2000) describes "endophytes are microorganisms which have ability to colonize living, internal tissue of plant without causing any immediate negative effects". Schulz and Boyle (2006) defined endophytic bacteria are those bacteria that colonize the internal tissues of plants without causing any external sign of infection or showing negative effect on their host. The definition of endophytes given by Hallmann et al., (1997) seems to be most appropriate. They defined endophytic bacteria resides inside the surface sterilized plant tissues or can be isolated from inside the plant tissue and having no harmful effect on the host plants. But this definition cannot be applied to nonculturable endophytes therefore definitions of endophytes by Bulgarelli et al., 2013 seems to be more appropriate definitions which defines endophytes as a set of microbial genomes located inside plants organs.

\section{Isolation of bacterial endophytes}

In general endophytic bacterial population are lower than rhizospheric bacterial pathogens. (Hallmann et al., 1997; Rosenblueth and Martínez-Romero, 2004). The endophytic environment gives the protection from outer environment to those bacteria which colonize the internal tissue of plants. These bacteria generally colonize the internal tissue of plants, and they have been isolated from all the parts of plants including seeds (Posada and Vega, 2005). Endophytic bacteria have been isolated from both leguminous and nonleguminous plants. Endophytic bacteria can be isolated and characterized from internal tissues of plant by sterilizing the surface with sodium hypochlorite or similar agents (Lodewyckx et al., 2002; Miche and Balandreau, 2001). Kobayashi and Palumbo (2000) reported $10^{2}$ to $10^{4}$ viable endophytic bacteria in of sample. 65 bacterial endophytes were isolated from stem roots and nodules by Hung and
Annapurna (2004). Similarly Saini et al., (2015) isolated endophytic bacteria from roots (12 isolates) and nodules (76 isolates) of chickpea legume grown under CCS Haryana Agricultural University farm. GhodhbaneGtari et al., (2014) isolated Actinobacterium strain BMG51109a from surface sterilized root nodules of Casuarina glauca collected from Tunisia.

\section{Plant growth promotion by ecofriendly endophytes}

Endophytic bacteria differs from rhizospheric bacteria in terms of living inside the plant tissues but employ similar plant growth promotion mechanisms as that of rhizospheric organisms. As endophytes lives inside the plant tissue therefore, it is likely that endophytic plant growth promoting bacteria will be superior to similar non-endophytic bacterial in terms of protection and promotes plant growth under a wide range of environmental conditions. Plant-growthpromoting bacterial endophytes (PGPBEs) facilitate plant growth via three interrelated mechanisms: phytostimulation, biofertilization and biocontrol (Bloemberg and Lugtenberg, 2001).

Phytostimulation includes ACC (1aminocyclopropane-1-carboxylate) utilization and indole acetic acid production, biofertilization includes nitrogen fixation, phosphate solubilisation and potassium solubilisation and bioconrol include siderophore production (Fig. 2).

\section{Phytostimulation}

Phytostimulation is the direct promotion of plant growth through the production of phytohormones (Bloemberg and Lugtenberg, 2001). The most highly studied example of phytostimulation involves lowering plant hormone ethylene levels by the enzyme 1- 
aminocyclopropane-1-carboxylate

$(\mathrm{ACC})$ deaminase and indole acetic acid (IAA) production.

\section{ACC utilization by endophytes}

Under normal conditions, ethylene helps in germination of seeds root hair growth and fuit ripening (Abeles et al., 1992; Siddikee et al., 2010). But, during the stress response, plant produce high level of ethylene that acts opposite to normal function and is harmful to the plant growth. The bacterial endophytes have capability to produce ACC deaminase enzyme which promotes the plant growth by converting ACC to ammonia and alpha ketobutyrate. Rhizobial strains that produce active ACC deaminase, contained a relatively low level of ethylene activity (approximately 2-8\%) compared with the amount of enzyme activity generally found in free-living soil bacteria (Zahir et al., 2003). Various Bacillus strain (Bacillus circulans, Bacillus firmus, Bacillus globisporus) have potential to produce ACC deaminase, reported to stimulate the root elongation in Brassica camprestris (Ghosh et al., 2003). Apart from the bacillus strain Pseudomonas spp. also have ability to produce ACC deaminase and there by increased the dry matter contents of root when inoculated in seeds (Reed and Glick, 2005). Some of the studies reported that some ACC deaminase producing bacteria have potential to promote plant growth in various stressful conditions like drought, saline conditions and flooding.

High salt conditions suppresses the growth of plants because during the stress conditions ACC production by plants increases. Bacterium Achromobacter piechaudii isolated from soil of Lycium shawii have capacity to produce ACC deaminase. Under salt stress conditions, this bacterium is inoculated with the seed of tomato, were significantly reduced ACC production and increased the dry and fresh tomato seedlings weight (Mayak et al., 2004). Etesami et al., (2104) showed in their studies that under the flooded conditions ACC deaminase producing Pseudomonas fluorescence increased the rice seedlings significantly reported that ACC deaminase containing P. fluorescens REN1 increased in vitro root elongation and endophytically colonized the root of rice seedlings significantly, under constant flooded conditions.

\section{Production of phytohormones}

Among the five major classes of phytohormone auxin, gibberellins, ethylene, abscisic acid and cytokinins, indole acetic acid (IAA) is the most abundant phytohormone which belongs to the auxin family, improves plant growth (Tsakelova et al., 2006). IAA helps the plants by production of longer roots and also increase density of roots which helps is more nutrient uptake (Datta and Basu, 2000). Various studies revealed that endophytic bacteria promote plant growth significantly by production of phytohormones.

These phytohormones are important for plant growth as they regulate the various biological processes, fruit development, cell division and senescence. Indole acetic acid induce cell elongation by increasing the permeability of water in to the cells, increasing ostomic contents of the cells and by decreasing wall pressure. It also induces the flowering and fruiting and delay the abscission of leaves (Zhao, 2010).

It is reported that about $80 \%$ of the naturally occurring microorganisms in soil are capable for indole acetic acid production (Patten and Glick, 1996; Khalid et al., 2004; Loper and Schroth, 1986). Some rhizobial species are known to produce indole acetic acid in the rhizospheric soil (Bhattacharyya and Jha, 2012; Spaepen et al., 2009). 


\section{Biofertilization}

Increasing the supply of utilizable form of nutrients to plants for growth promotion is defined as biofertilization (Bashan, 1998). Nitrogen fixation and phosphorus solubilisation is the best studied example of biofertilization (Bloemberg and Lugtenberg, 2001).

\section{Nitrogen $\left(\mathbf{N}_{2}\right)$ fixation}

Nitrogen plays a important role in plant growth and is usually absorbed by plants as nitrate or ammonium ions. It is the essential elements of metabolism of plants and very important for making proteins, enzymes and chlorophyll structure of plants. Soils which are deficient in nitrogen, usually result in low crop yield. Farmers supply nitrogen to agricultural land in the form chemical fertilizers such as urea and ammonium nitrate. Low amount of these chemical fertilizers is used to stimulate the growth of plants and also required to induce the activity of nitrogen fixing bacteria (Jefing et al., 1992). But these chemical fertilizers harm the environment in various ways, therefore, researchers are focused to develop the ecofriendly agriculture practices, for example by applying the biofertilizers like endophytic bacteria. Rhizobium is the best example to fix nitrogen in a sustainable manner. These microorganisms were traditionally considered to be responsible for legume infection process, however rhizobia can behave as endophytes in nodules and the isolated rhizobial strain from nodule have ability to again infect the similar legumes from which they were recovered and also promote their growth. Lei et al., (2008) isolated the endophytic rhizobia from the vicia nodules. Two of the endophytes $R$. leguminosarum and Mesorhizobium loti were isolated from the clover nodules and when these were coinoculated, showed increase in plant growth (Strutz et al., 1997).
As the legumes possess nodules on their roots where this bacterium Rhizobium locates with a defined function of converting the atmospheric $\mathrm{N}_{2}$ into plant available form, called biological nitrogen fixation. Increases in amount of biological nitrogen fixation can result from the use of different commercial or wild strains. Significant increase in biological nitrogen fixation suggests that more nitrogen can be fixed if they are inoculated more often or with more effective rhizobia. In this manner, an appreciable quantity of biological nitrogen is accumulated in the soil which can be used by similar crop and the subsequent one. Two main reason for the low crop yield is unavailability of good quality seeds and effective rhizobial inoculation. Seed treated with native rhizobia in soil lacking effective rhizobia is useful for improving nodulation and crop yield (Rupela and Dart, 1979; Patil and Sbinde, 1980; Shamim and Ali, 1987; Shah et al., 1994). Chickpea respond positive to rhizobial inoculation when grown in soils that contain native rhizobia (Sharma et al., 1983). However with the introduction of improved varieties or sowing of this crop in new areas, inoculations with effective rhizobial strain is essential for getting higher yields. Apart from the rhizobial endophytes there are some promising nonrhizobial endophytic biofertilizers that include the members of Azoarcus, Achromobacter, Burkholderia, Gluconoacetobacter, Herbaspirillum, Klebsiella and Serratia (Rothballer et al., 2008; Frache et al., 2009). The sufficient nitrogen supply by endophytic diazotropic bacteria in kallar grass and sugarcane suggest that endophytic bacteria can have potential to fix biological nitrogen fixation in sufficient amount. Gluconoacetobacter diazotrophicus (Acetobacter diazotrophicus) is an endophytes, has potential to fix nitrogen in sugarcane and can fix nitrogen approximately $150 \mathrm{Kg} \mathrm{N}^{-1}$ year $^{-1}$ (Dobereiner et al., 1993; Muthukumarassamy et al., 2005). 
Fig.1 Benefit of using endophytes over chemical fertilizers
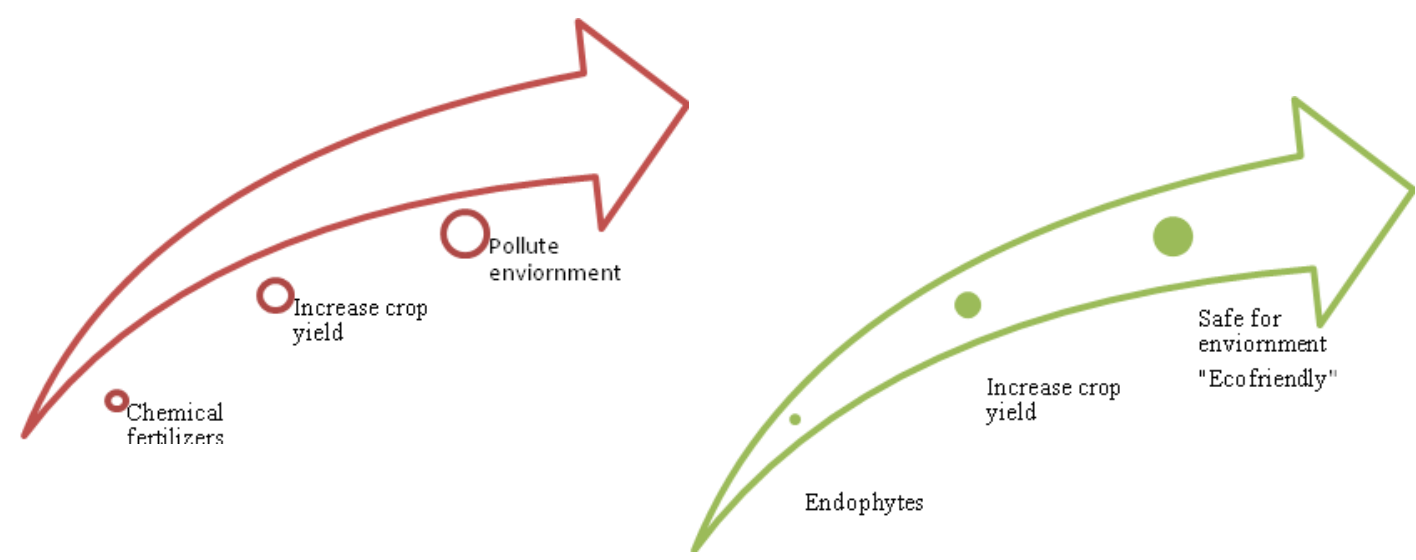

Fig.2 Plant growth promoting activity of bacterial endophytes

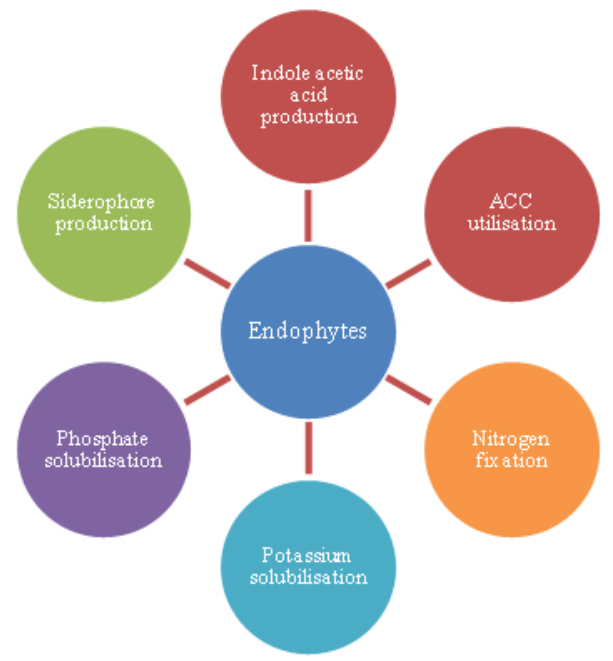

Fig.3 Rhizobial and nonrhizobial culture as bioinoculant
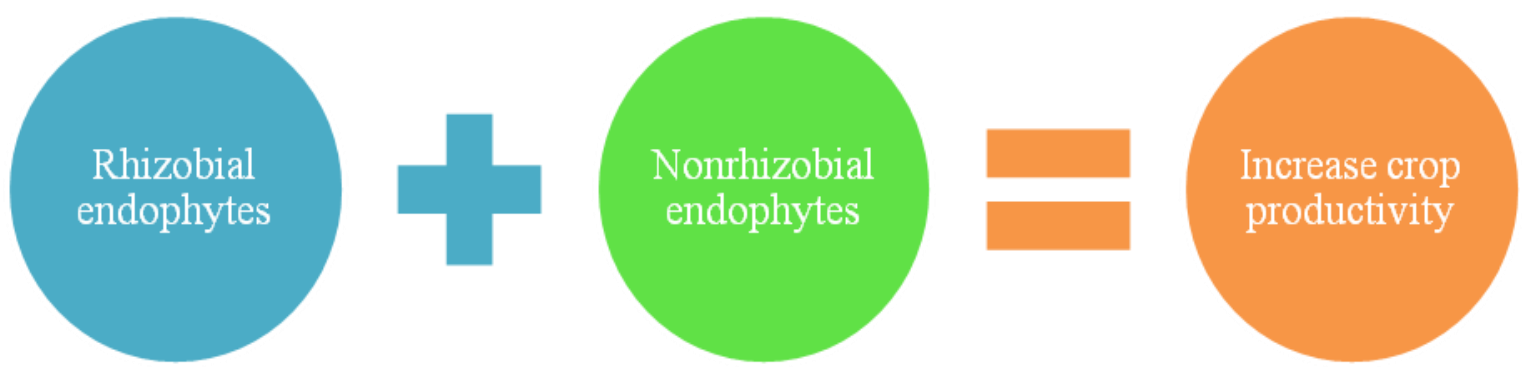
These investigations suggest that both rhizobial as well as nonrhizobial endophytic bacteria have potential to increase the productivity of plants. Thus these can used as bioinoculant and can improves more productivity when coinoculated (Fig. 3).

\section{Phosphate solubilisation}

Phosphorous is one of the most important nutrient for plants and also second most limiting factor. Phosphorous plays a central role in genetic structures, photosynthesis and energy transfer (Kim et al., 1998). It is a limiting factor because it is found in soil in bound form that cannot be utilized by plants quickly. Thus in agriculture practices farmer utilizes the fertilizers which heavily contaminate the environment. Thus alternate to this is use of micro-oraganisms such as ecofriendly bacteria. Various research publications also showed that alternate to this problem is to use phosphate solubilizing microorganisms as a biofertilizers (Richardson, 2001).

Bacteria like Bacillus, Pseudomonas and Rhizobium have capability to solubilise the phosphorus (Sridevi et al., 2007; Rodriguez and Fraga, 1999). A strain of Bacillus megaterium when applied to seed of chickpea plant also significantly increased the plant height, nodule dry weight, root, shoot, nitrogen percentage, chlorophyll content pod number seed protein and total biomass yield as compared to control and mineral fertilizers applications in the field as well as controlled environment conditions (Elkoca et al., 2007). A study by Oteino et al., (2015) described that endophytic Pseudomonas isolates showed that many endophytic strains differ in their potential to solubilize phosphorus when inoculated to pea plant grown in soil and also showed beneficial plant growth promoting effects under the limiting soluble phosphate. Bacterium Mesorhizobium (Rhizobium) when applied to soil containing insoluble phosphorous have capability to enhance the chickpea plant growth by solubilising the phosphorus (Peix et al., 2001). The studied reveals that his strain has efficiency to mobilize phosphorous when TCP (tricalcium phosphate) was added in the experimental soil. Also this study by Peix et al., (2001) showed that when the bacterial culture was inoculated in the soil, the soluble phosphorus content was increased as compared to the uninoculated soil and also magnesium content, calcium content, plant dry matter was significantly increased in comparison studies.

\section{Potassium solubilisation}

Potassium is one of the most essential micronutrient and has important role in development of plants. If the potassium is not available to plants, the plants will show characters weak root development, stunted growth, small seeds and low yield. The soil contains the potassium in large amount but problem is that it is found in unavailable form which cannot be utilized by plants directly. Thus the farmers rely on agrochemical which pollute the environment as well as increase the cost of agriculture. Microorganisms are used now days to solve the above problem to make potassium availability to plants (Rogers et al., 1998; Groudev, 1987). A number of bacteria namely Pseudomonas, Rhizobium, Bacillus and Paenibacilus have been reported in studies to make unavailable potassium to available form for plants (Badr et al., 2006). Inoculation of plants with this potassium solubilising bacteria resulted in higher mobilization of potassium from insoluble form thus helps in wheat and maize plant growth promotion (Singh et al., 2010). Thus the application of potassium solubilising bacteria can reduce the environment pollution by agrochemicals and can support the crop production in ecofriendly way (Sheng et al., 2013). 


\section{Biocontrol}

Microorganisms protect plants from phytopathogen by various mechanisms termed as biocontrol. Endophytes produce siderophore is one of the mechanisms of plant protection as wells as plant growth promotion.

\section{Siderophore production}

Iron $(\mathrm{Fe})$ is the essential micronutrient for plants as it is required for many processes such as photosysntheis, DNA synthesis, respiration and nitrogen fixation. Iron is the present in large amount in soil as it is the fourth most abundant element of earth crust. But this iron is not available to plants because most of it is found in insoluble form. If the iron is not available to plants, it results in chlorosis. So this problem can be solved by the endophytic bacteria as they have ability to dissolve this insoluble iron by producing siderophore and hence making the availability to the plants. The microorganisms produce siderophore in iron limiting conditions, making insoluble form of iron to soluble forms it is defined as low molecular weight chelating compounds which chelate iron from the environment. There are various type of siderophore produce by endophytes such as rhizobactin, enterobactin and ferrioxamine. As the siderophore produced by endophytes help the plants by making iron available to plant, second it can act as a biocontrol agent by removing the iron from phytopathogen in the iron limiting conditions. Fusarium Oxysprium is a phytopathogen and its growth is inhibited by the indigenous strain Bacillus Subtilis by producing siderophore thus can act as a biocontrol agent and indirectly promote plant growth (Patil et al., 2014).

\section{Field application of endophytes}

Some research has shown that endophytes have a great potential to increase the yield of different plants when they are inoculated. Coinoculation of rhizobial endophytes and nonrhizobacterial endophytes had reported to increase the yield of plant in a significant manner (Harish et al., 2009). To use the rhizobial and nonrhizobial coinoculation in the field, one thing must considered before applying in field, that these endophytes are compatible with each other and do not inhibit the growth of each other. Santiago et al., (2017) used compatible bioinoculants in their experiment to increase the potato crop yield. Various studies reported that single inoculations can increase the yield of crops but when both rhizobial and nonrhizobial culture applied to a crop, the percentage of crop yield increase from single inoculations Stajković et al., (2009). The most important benefit of using these endophytic biofertilizers to field is that it can be useful to subsequent crops also as these bacterial endophytes have ability to multiply. Thus the farmer has benefits, to use these endophytes as biofertilizers rather than using the fertilizers as these were ecofriendly, cheap and can be used for subsequent crops in a sustainable manner.

Agriculture has a great importance in the livelihood of the human being. But now days, to increase the agriculture productivity chemical fertilizers are used in high quantity which are polluting the environment. As Environment pollution is the one of the biggest problem in the world so alternate of this is to use the ecofriendly endophytes which have potential to increase the agriculture productivity as well as safe for environment.

\section{References}

Abeles, F. W. (1992). Roles and physiological effects of ethylene in plant physiology: dormancy, growth, and development. Ethylene in Plant Biology. 
Bacon, C. W., and J. F. White. 2000. Microbial endophytes. Marcel Dekker Inc., New York, N.Y

Badr, M. A., Shafei, A. M., and Sharaf ElDeen, S. H. (2006). The dissolution of $\mathrm{K}$ and P-bearing minerals by silicate dissolving bacteria and their effect on sorghum growth. Research Journal of Agriculture and Biological Sciences, 2(1), 5-11.

Baldani, V. D., Baldani, J. I., and Döbereiner, J. (2000). Inoculation of rice plants with the endophytic diazotrophs Herbaspirillum seropedicae and Burkholderia spp. Biology and Fertility of Soils, 30(5-6), 485-491.

Bary, A. (1866). Morphologie und physiologie der pilze, flechten und myxomyceten. W. Engelmann.

Bashan, Y. (1998). Inoculants of plant growth-promoting bacteria for use in agriculture. Biotechnology advances, 16(4), 729-770.

Bhattacharjee, R. B., Singh, A., and Mukhopadhyay, S. N. (2008). Use of nitrogen-fixing bacteria as biofertiliser for non-legumes: prospects and challenges. Applied microbiology and biotechnology, 80(2), 199-209.

Bhattacharyya, P. N., and Jha, D. K. (2012). Plant growth-promoting rhizobacteria (PGPR): emergence in agriculture. World Journal of Microbiology and Biotechnology, 28(4), 1327-1350.

Bloemberg, G. V., and Lugtenberg, B. J. (2001). Molecular basis of plant growth promotion and biocontrol by rhizobacteria. Current opinion in plant biology, 4(4), 343-350.

Bloemberg, G. V., and Lugtenberg, B. J. (2001). Molecular basis of plant growth promotion and biocontrol by rhizobacteria. Current opinion in plant biology, 4(4), 343-350.

Bulgarelli, D., Schlaeppi, K., Spaepen, S., van
Themaat, E. V. L., and Schulze-Lefert, P. (2013). Structure and functions of the bacterial microbiota of plants. Annual review of plant biology, 64, 807-838.

Cornelis, P. (2010). Iron uptake and metabolism in pseudomonads. Applied microbiology and biotechnology, 86(6), 1637-1645.

Datta, C., and Basu, P. S. (2000). Indole acetic acid production by a Rhizobium species from root nodules of a leguminous shrub, Cajanus cajan. Microbiological research, 155(2), 123-127.

Döbereiner, J., Reis, V. M., Paula, M. A., and Olivares, F. D. (1993). Endophytic diazotrophs in sugar cane, cereals and tuber plants. In New horizons in nitrogen fixation (pp. 671-676). Springer Netherlands.

Elkoca, E., Kantar, F., and Sahin, F. (2007). Influence of nitrogen fixing and phosphorus solubilizing bacteria on the nodulation, plant growth, and yield of chickpea. Journal of Plant Nutrition, 31(1), 157-171.

Etesami, H., Hosseini, H. M., Alikhani, H. A., and Mohammadi, L. (2014). Bacterial biosynthesis of 1-aminocyclopropane-1carboxylate (ACC) deaminase and indole-3-acetic acid (IAA) as endophytic preferential selection traits by rice plant seedlings. Journal of plant growth regulation, 33(3), 654-670.

Franche, C., Lindström, K., and Elmerich, C. (2009). Nitrogen-fixing bacteria associated with leguminous and nonleguminous plants. Plant and soil, 321(1-2), 35-59.

Freeman, E. M. (1904). The seed-fungus of Lolium temulentum, L., the Darnel. Philosophical Transactions of the Royal Society of London. Series B, Containing Papers of a Biological Character, 196, 1-27.

Ghodhbane-Gtari, F., Hurst, S. G., Oshone, 
R., Morris, K., Abebe-Akele, F., Thomas, W. K.,... and Tisa, L. S. (2014). Draft genome sequence of Frankia sp. strain BMG5. 23, a salttolerant nitrogen-fixing actinobacterium isolated from the root nodules of Casuarina glauca grown in Tunisia. Genome announcements, 2(3), e00520-14.

Ghosh, S., Penterman, J. N., Little, R. D., Chavez, R., and Glick, B. R. (2003). Three newly isolated plant growthpromoting bacilli facilitate the seedling growth of canola, Brassica campestris. Plant Physiology and Biochemistry, 41(3), 277-281.

Groudev, S. N. (1987). Use of heterotrophic microorganisms in mineral biotechnology. Engineering in Life Sciences, 7(4), 299-306.

Hallmann, J., Quadt-Hallmann, A., Mahaffee, W. F., and Kloepper, J. W. (1997). Bacterial endophytes in agricultural crops. Canadian Journal of Microbiology, 43(10), 895-914.

Harish, S., Kavino, M., Kumar, N., Balasubramanian, P., and Samiyappan, R. (2009). Induction of defense-related proteins by mixtures of plant growth promoting endophytic bacteria against Banana bunchy top virus. Biological Control, 51(1), 16-25.

Hennig, K., and Villforth, F. (1940). Experimentelle untersuchungen zur frage der bakteriensymbiose in hoheren pflanzen und ihrer beeinflussung durch leitelemente. Biochem. Z, 305, 299-309.

Hung, P. Q., and Annapurna, K. (2004). Isolation and characterization of endophytic bacteria in soybean (Glycine sp.). Omonrice, 12, 92-101.

Hurek, T., and Reinhold-Hurek, B. (2003). Azoarcus sp. strain BH72 as a model for nitrogen-fixing grass endophytes. Journal of Biotechnology, 106(2), 169-178.
Jefing, Y., Herridge, D. F., Peoples, M. B., and Rerkasem, B. (1992). Effects of N fertilization on $\mathrm{N} 2$ fixation and $\mathrm{N}$ balances of soybean grown after lowland rice. Plant and Soil, 147(2), 235-242.

Kado, C. I. (1992). Plant pathogenic bacteria. The prokaryotes, 1, 659-674.

Khalid, A., Arshad, M., and Zahir, Z. A. (2004). Screening plant growth- promoting rhizobacteria for improving growth and yield of wheat. Journal of Applied Microbiology, 96(3), 473-480.

Kim, K. Y., Jordan, D., and McDonald, G. A. (1998). Enterobacter agglomerans, phosphate solubilizing bacteria, and microbial activity in soil: effect of carbon sources. Soil Biology and Biochemistry, 30(8), 995-1003.

Kirchhof, G., Reis, V. M., Baldani, J. I., Eckert, B., Döbereiner, J., and Hartmann, A. (1997). Occurrence, physiological and molecular analysis of endophytic diazotrophic bacteria in gramineous energy plants. In Opportunities for Biological Nitrogen Fixation in Rice and Other Non-Legumes (pp. 45-55). Springer Netherlands.

Kloepper, J. W., and Schroth, M. N. (1978, August). Plant growth-promoting rhizobacteria on radishes. In Proceedings of the 4th international conference on plant pathogenic bacteria(Vol. 2, pp. 879-882).

Kobayashi, D. Y., and Palumbo, J. D. (2000). Bacterial endophytes and their effects on plants and uses in agriculture. Microbial endophytes, 19 , 199-233.

Kuklinsky- Sobral, J., Araújo, W. L., Mendes, R., Geraldi, I. O., Pizzirani- Kleiner, A. A., and Azevedo, J. L. (2004). Isolation and characterization of soybean- associated 
bacteria and their potential for plant growth promotion. Environmental microbiology, 6(12), 1244-1251.

Lei, X., Wang, E. T., Chen, W. F., Sui, X. H., and Chen, W. X. (2008). Diverse bacteria isolated from root nodules of wild Vicia species grown in temperate region of China.Archives of microbiology, 190(6), 657-671.

Link, H. F. (1809). Observationes in ordines plantarum naturales: Dissertatio Ima complectens anandrarum ordines epiphytas, mucedines gastromycos et fungos.

Lodewyckx, C., Mergeay, M., Vangronsveld, J., Clijsters, H., and Van Der Lelie, D. (2002). Isolation, characterization, and identification of bacteria associated with the zinc hyperaccumulator Thlaspi caerulescens subsp. calaminaria. International Journal of Phytoremediation, 4(2), 101-115.

Loper, J. E., and Schroth, M. N. (1986). Influence of bacterial sources of indole3 -acetic acid on root elongation of sugar beet. Phytopathology, 76(4), 386-389.

Mayak, S., Tirosh, T., and Glick, B. R. (2004). Plant growth-promoting bacteria that confer resistance to water stress in tomatoes and peppers. Plant Science, 166(2), 525-530.

Miché, L., and Balandreau, J. (2001). Effects of rice seed surface sterilization with hypochlorite on inoculated Burkholderia vietnamiensis. Applied and environmental microbiology, 67(7), 3046-3052.

Muthukumarasamy, R., Cleenwerck, I., Revathi, G., Vadivelu, M., Janssens, D., Hoste, B.,... and Caballero-Mellado, J. (2005). Natural association of Gluconacetobacter diazotrophicus and diazotrophic Acetobacter peroxydans with wetland rice. Systematic and applied microbiology, 28(3), 277-286.

Oteino, N., Lally, R. D., Kiwanuka, S., Lloyd,
A., Ryan, D., Germaine, K. J., and Dowling, D. N. (2015). Plant growth promotion induced by phosphate solubilizing endophytic Pseudomonas isolates. Frontiers in microbiology, 6 .

Patil, R. N., and Shinde, P. A. (1980). Studies on nodulation pattern in gram (Cicer arietinum L.). Journal of Maharashtra Agricultural Universities, 5(3), 211213.

Patil, S., Bheemaraddi, C. M., Shivannavar, T. C., and Gaddad, M. S. (2014). Biocontrol activity of siderophore producing Bacillus subtilis CTS-G24 against wilt and dry root rot causing fungi in chickpea. IOSR J Agric Vet Sci, 7(9), 63-8.

Patten, C. L., and Glick, B. R. (1996). Bacterial biosynthesis of indole-3-acetic acid. Canadian journal of microbiology, 42(3), 207-220.

Peix, A., Rivas-Boyero, A. A., Mateos, P. F., Rodriguez-Barrueco, C., MartınezMolina, E., and Velazquez, E. (2001). Growth promotion of chickpea and barley by a phosphate solubilizing strain of Mesorhizobium mediterraneum under growth chamber conditions. Soil Biology and Biochemistry, 33(1), 103110.

Perotti, R. (1926). On the limits of biological enquiry in soil science. Proc. Int. Soc. Soil Sci., 2, 146-161.

Petrini. (1991). O. Fungal endophytes of tree leaves. Andrews JH, Hirano $S S$. Microbial Ecology of Leaves. New York: Springer 鄄Verlag, 179.

Posada, F., and Vega, F. E. (2005). Establishment of the fungal entomopathogen Beauveria bassiana (Ascomycota: Hypocreales) as an endophyte in cocoa seedlings (Theobroma cacao). Mycologia, 97(6), 1195-1200.

Reed, M. L., and Glick, B. R. (2005). Growth of canola (Brassica napus) in the 
presence of plant growth-promoting bacteria and either copper or polycyclic aromatic hydrocarbons. Canadian Journal of Microbiology, 51(12), 10611069.

Reinhold-Hurek, B., and Hurek, T. (1998). Interactions of gramineous plants with Azoarcus spp. and other diazotrophs: identification, localization, and perspectives to study their function. Critical Reviews in Plant Sciences, 17(1), 29-54.

Richardson, A. E. (2001). Prospects for using soil microorganisms to improve the acquisition of phosphorus by plants. Functional Plant Biology, 28(9), 897-906.

Rodríguez, H., and Fraga, R. (1999). Phosphate solubilizing bacteria and their role in plant growth promotion. Biotechnology advances, 17(4), 319-339.

Rogers, J. R., Bennett, P. C., and Choi, W. J. (1998). Feldspars as a source of nutrients for microorganisms. American Mineralogist, 83(11), 1532-1540. Badr, M. A., Shafei, A. M. and Sharaf, S. H. (2006). The dissolution of $\mathrm{K}$ and phosphorus bearing minerals by silicate dissolving bacteria and their effect on sorghum growth. Journal of Agriculture and Biological Sciences 2: 5-11.

Rosenblueth, M., and Martínez-Romero, E. (2004). Rhizobium etli maize populations and their competitiveness for root colonization. Archives of microbiology, 181(5), 337-344.

Rothballer, M., Eckert, B., Schmid, M., Fekete, A., Schloter, M., Lehner, A.,... and Hartmann, A. (2008). Endophytic root colonization of gramineous plants by Herbaspirillum frisingense. FEMS microbiology ecology, 66(1), 85-95.

Saini, R., Dudeja, S. S., Giri, R., and Kumar, V. (2015). Isolation, characterization, and evaluation of bacterial root and nodule endophytes from chickpea cultivated in Northern India. Journal of basic microbiology, 55(1), 74-81.

Santiago, C. D., Yagi, S., Ijima, M., Nashimoto, T., Sawada, M., Ikeda, S.,... and Ohwada, T. (2017). Bacterial Compatibility in Combined Inoculations Enhances the Growth of Potato Seedlings. Microbes and environments, 32(1), 14-23.

Schulz, B. (2006). What are endophytes? En: B. Schulz, CJ Boyle and TN Sieber.(eds.). Microbial root endophytes. Springer, Berlin, Heidelberg, 9, 13.

Shah, S. H., Khan, D. F., and Madani, M. S. (1994). Effect of different rhizobial strains on the performance of two chickpea cultivars under field conditions. Sarhad Journal of Agriculture, 10, 103-103.

Shamim, M., and Ali, N. (1987). Effect of seed Inoculation with rhizobium and NP fertilizer levels on the yield of gram. Pakistan Journal of Agricultural Research (Pakistan).

Sharma, L. C., Saxena, S., Jain, R. K., Prasad, J., and Reddy, B. N. (1983). Survey for nodulation in gram in Rajasthan. International Chickpea Newsletter, 9, 24-25.

Sheng, X. F., Xia, J. J., and Chen, J. (2003). Mutagenesis of the Bacillus edaphicus strain NBT and its effect on growth of chili and cotton. Agricultural Sciences in China, 2(4), 409-412.

Siddikee, M. A., Chauhan, P. S., Anandham, R., Han, G. H., and Sa, T. (2010). Isolation, characterization, and use for plant growth promotion under salt stress, of ACC deaminase-producing halotolerant bacteria derived from coastal soil. $J$ Microbiol Biotechnol, 20(11), 1577-1584.

Singh, A. V., Birendra, P., and Shachi, S. (2010). Screening plant growth 
promotory rhizobacteria for improving seed germination and seedling vigor of lentil (Lens culinaris Medik). Environment and Ecology, 28(3B), 2055-2058.

Spaepen, S., Vanderleyden, J., and Okon, Y. (2009). Plant growth-promoting actions of rhizobacteria. Advances in botanical research, 51, 283-320.

Sridevi, M., Mallaiah, K. V., and Yadav, N. C. S. (2007). Phosphate solubilization by Rhizobium isolates from Crotalaria species. J Plant Sci, 2, 635-639.

Stajković, O., De Meyer, S., Miličić, B., and Willems, A. (2009). Isolation and characterization of endophytic nonrhizobial bacteria from root nodules of alfalfa (Medicago sativa L.). Botanica serbica, 33(1), 107-114.

Sturz, A. V., Christie, B. R., Matheson, B. G., and Nowak, J. (1997). Biodiversity of endophytic bacteria which colonize red clover nodules, roots, stems and foliage and their influence on host growth. Biology and Fertility of Soils, 25(1), 13-19.

Taylor, T. N., and Taylor, E. L. (2000). The Rhynie chert ecosystem: a model for understanding fungal interactions. Microbial endophytes, 31-
47.

Tervet, W. and Hollis, P. (1948). Bacteria in the storage organs of healthy plants. Phytopathology 38: 960-967.

Tsavkelova, E. A., Klimova, S. Y., Cherdyntseva, T. A., and Netrusov, A. I. (2006). Microbial producers of plant growth stimulators and their practical use: a review. Applied Biochemistry and Microbiology, 42(2), 117-126.

Vogl, A. (1898). Mehl und die anderen Mehlprodukte der Cerealien und Leguminosen. Nahrungsm Unters Hyg Warenk, 12, 25-29.

Wilson, D. (1993). Fungal endophytes: out of sight but should not be out of mind. Oikos, 379-384.

Zahir, Z. A., Arshad, M., and Frankenberger, W. T. (2003). Plant growth promoting rhizobacteria: applications and perspectives in agriculture. Advances in Agronomy, 81, 97-168.

Zhao, L., Xu, Y., Sun, R., Deng, Z., Yang, W., and Wei, G. (2011). Identification and characterization of the endophytic plant growth prompter Bacillus cereus strain MQ23 isolated from Sophora alopecuroides root nodules. Brazilian Journal of Microbiology, 42(2), 567575.

\section{How to cite this article:}

Priyanka Batra, Monika Barkodia, Umang Ahlawat, Rekha Sansanwal, Tanisha Sharma and Leela Wati. 2018. Endophytes: An Environmental Friendly Bacteria for Plant Growth Promotion. Int.J.Curr.Microbiol.App.Sci. 7(02): 1899-1911. doi: https://doi.org/10.20546/ijcmas.2018.702.229 